\title{
Out-Migration in Search of Livelihood: A study of the Rajbanshi Migrants from Koch Bihar, West Bengal
}

\author{
Ushasi Basu Roy Chowdhury ${ }^{1}$, Prasanta Ray ${ }^{2}$ and Ranjan Basu ${ }^{3}$ \\ ${ }^{I}$ (Research Scholar, Department of Geography, University of Calcutta, India) \\ ${ }^{2}$ (Emeritus Professor, Department of Sociology, Presidency University, India and Honorary Visiting Professor, \\ Institute of Development Studies Kolkata, India) \\ 3 (Professor, Department of Geography, University of Calcutta, India)
}

\begin{abstract}
A large number of Rajbanshi people had moved out of Koch Bihar, West Bengal in search of livelihood. This paper finds out the reason behind this out-migration and seeks to understand its nature. This is an ethnographic study. The reasons of migration stated by the Rajbanshi migrants have been examined with the relevant secondary data. Separate BORDA Composite Indices for demographic and economic attributes for all the districts of West Bengal had been constructed. In addition, similar Indices for rural employment as well as income and different amenities present in villages of all the districts of West Bengal have been constructed. Based on these indices it can be inferred that the performance of Koch Bihar district is not satisfactory. The analysis highlighted that livelihood migration among this particular community is due to certain compelling forces.
\end{abstract}

Keywords: deprived, development, facilities, migration, voluntary.

\section{INTRODUCTION}

This paper seeks to understand the reasons behind the out-migration for earning a livelihood of the Rajbanshis from Koch Bihar, West Bengal to Jaipur, Rajasthan. The reasons Stated by these Rajbanshi migrants of their coming out of the native place have been analyzed with the relevant secondary data - mainly, official data -- in order to understand the nature of this livelihood-driven migration.

Before understanding the nature of the livelihood migration among the people belonging to the Rajbanshi community here it will be appropriate to understand their historical background. The Rajbanshi community was both indigenous and predominant Hindu population in northern part of West Bengal. They were backward in terms of education and agriculture was their major occupation. Prior to the Indian independence, they were victims of deteriorating economic condition i.e., their transformation from landholders to sharecroppers due to domination of the immigrant 'upper caste Hindu Bengalis', identity crisis as well as divide and policy rule of the colonial government.

After independence, in India the Rajbanshis got settled in West Bengal, Assam, Meghalaya and Bihar. In West Bengal they are mainly concentrated in the Koch Bihar district which was a Princely State during the colonial period. After Indian independence, the Princely State was merged with India and an 'Instrument of Accession' was signed on $12^{\text {th }}$ September 1949. Prior to that both the sides signed a merger agreement on $28^{\text {th }}$ August 1949. The Maharaja of the then Cooch Behar, Jagaddipendranarayana Bhup Bahadur signed the agreement only after certain arrangements were made on his part one being the recognition of Cooch Behar State as "a Centrally-administered area under a Chief Commissioner" after merging with India which was also confirmed by the then Governor General of India V.P. Menon through a letter to the Maharaja dated $30^{\text {th }}$ August, 1949. But, it was forcefully incorporated as a district of West Bengal on $1^{\text {st }}$ January 1950 as a result of the role played by the then Chief Minister of West Bengal, Dr. Bidhan Chandra Roy. Soon after this the State language of West Bengal, its history and culture were forced upon this people. The partition of 1947 led to the influx of refugees from East Pakistan to different parts of India, which was also the case in Koch Bihar district of West Bengal. As a result the lands earlier belonged to the Rajbanshis were occupied by the refugees. The Indian Government supported this kind of infiltration of the refugees. They also supported immigrants from Bangladesh, which is also continuing at present. The land reform policy of the country benefitted these refugees and immigrants whereas land alienation occurred among the Rajbanshis and their State were deteriorated.

Going by the census data it emerges that the Rajbanshis are relatively deprived if we compare their status with the Namasudras, the Jalia Kaibarittas and the other population (includes both General and Other Backward Caste Population) in terms of level of urbanization, literacy rate, level of educational attainment and the types of works engaged with. The pamphlets of different organization and political parties who are behind the Kamtapur movement also reflect the same. Further, the underdevelopment led unemployment situation in 
north Bengal region forced the people belonging to this community to migrate from their homeland for earning their livelihood and became diaspora within India and outside more prominently to the Jaipur district of Rajasthan since 1965, which is continuing at present.

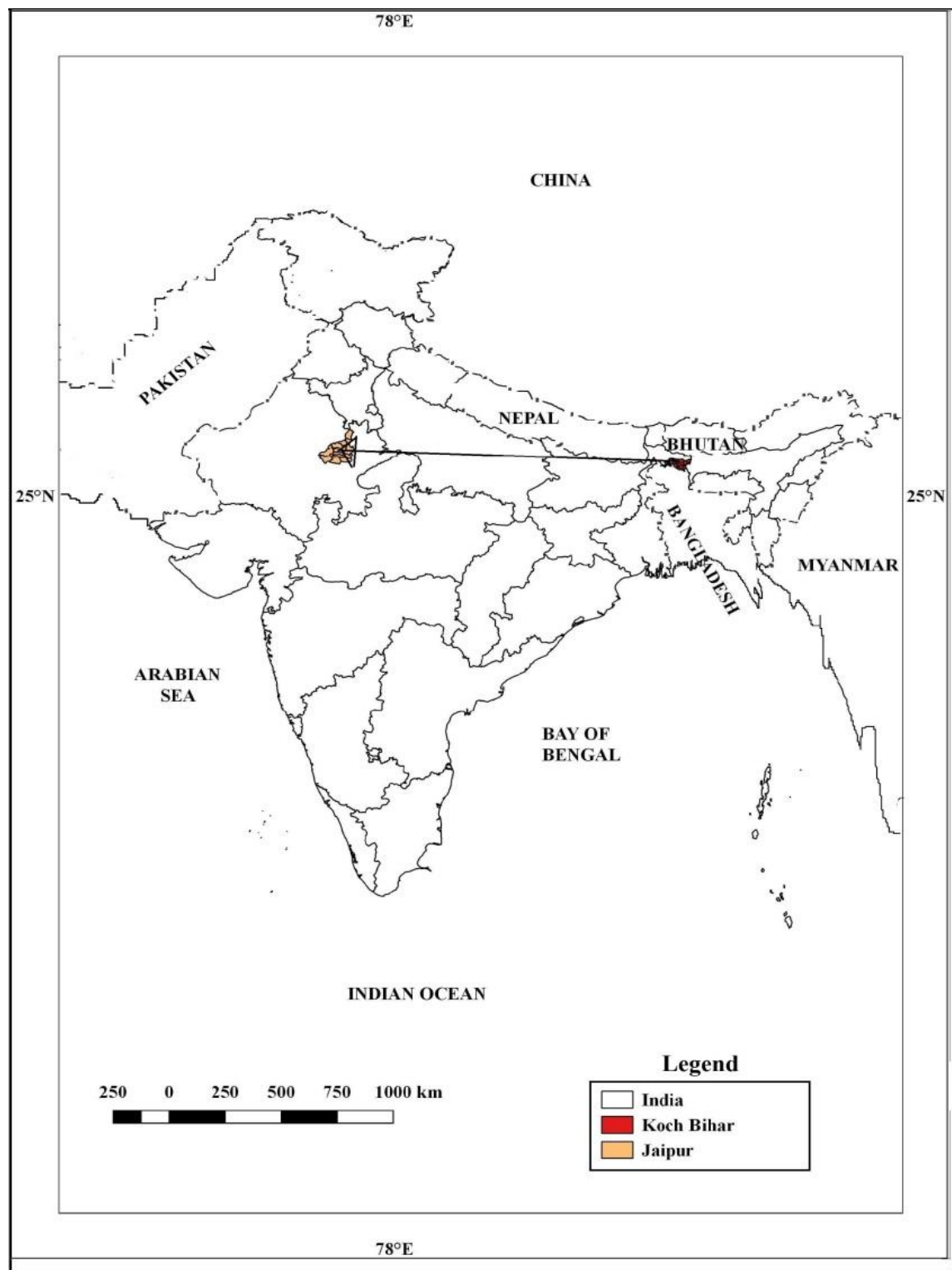

Source: Census of India

Figure 1 Outmigration from Koch Bihar, West Bengal to Jaipur, Rajasthan in India

\section{LITERATURE REVIEW}

Migration for earning a livelihood has been conceptualized as both voluntary and involuntary as can be observed from different researches in the past. The scholars who believed the voluntary nature of livelihood migration based their arguments on the rational calculation of the pros and cons of the destination place that a migrant will do before migrating (Ravenstine, 1885; Lewis, 1954; Ranis and Fei,1961; Harris and Todaro, 1970). On the other hand those scholars who viewed livelihood migration as involuntary Stated that there exist different factors such as class relations; divide and rule policy; slave trade; economic stagnation due to war, lopsided development, underutilization of labour force due to less economic opportunities and failure of economic policies which compel a person to migrate outside (Kautsky, 1899 (translated in 1988); Shrestha, 1985; Constantinou and Dimantides, 1985; Hart, 1986; Lawson and Brown, 1987; Bremen, 1989; Pincus, 1996; Sriskandarajah, 2002; Gidwani and Sivaramakrishnan, 2003; Lundholm et al., 2004; Kress, 2006; Parente et al., 2012; Wise, 2013; Kebbeh, 2013). Looking into the present scenario all over the world of increasing economic refugees and internal displacement due to economic stagnation and domination of certain groups of people on others, one needs to go beyond the most predominant notion of voluntary livelihood migration. What led 
towards the continuation of the Rajbanshi out-migration from Koch Bihar, West Bengal to Jaipur, Rajasthan and other parts of India namely Noida, Haryana, Mumbai and Kerala from 1965 onwards to the present need to be understood because the same community are also having regional aspirations and demanding a separate Statehood 'Kamtapur' ${ }^{1}$ through social movement since 1969.

\section{METHODOLOGY}

This paper is based on an ethnographic study of the Rajbanshi migrants in Jaipur, Rajasthan. Narrative enquiry was done in order to find out the reasons behind their out-migration from their native place Koch Bihar, West Bengal. These migrants are undocumented and therefore the actual population is unknown. A sample size of one hundred fifty households of Rajbanshi migrants had been taken for this particular study. Sample population was selected through purposeful random sampling ${ }^{2}$. Both primary data obtained from the fieldwork and secondary data collected from different government reports had been triangulated. Triangulation was also attempted during analysis. Both qualitative and quantitative analysis had been done. Under quantitative analysis, simple percentage calculation had been done wherever it was required. In order to calculate the present level of Development of the districts of West Bengal,Borda composite index ${ }^{3}$ had been constructed. It is a rank based composite index. First different indicators were chosen. The districts were ranked accordingly in terms of each indicator. All the ranks obtained by each district were then added up which gave the composite score. These composite scores were written in a separate column. Based on these composite values Borda rank was provided. Lower the composite value higher is the Borda rank and vice versa. Three Borda composite indices had been constructed each for demographic attributes, economic attributes, rural employment as well as income and percentage of villages having different amenities.

It is important to mention here that detailed district level data of the Rajbanshis in West Bengal related to various indicators were not available except their population size. Therefore, it was necessary to draw certain inferences from the rural scheduled caste data of Koch Bihar. The Rajbanshi community comprised about 76 percent of the total rural scheduled caste population in Koch Bihar in 2011. Therefore, the rural scheduled caste data of Koch Bihar had been analyzed which provided a good idea about the condition of the Rajbanshis in the district.

\section{FINDINGS AND DISCUSSION}

Ethnographic findings show variety of reasons for out-migration from Koch Bihar. About 47 percent of the sample population Stated that the income, which they used to earn in Koch Bihar, was not sufficient for their survival. 31 percent sample migrants stated unemployment as the reason for migration. 13 percent stated that they were not getting job throughout the year. Only seven percent of the respondents Stated that they migrated because of better opportunities and a meager one percent identified personal problems (family problems, party related problems etc.) as the reason for migration. The ethnographic findings also show that about 92 percent of the sample population was compelled to migrate out of Koch Bihar, West Bengal. However, there is dearth of secondary data, which can reflect when this type of out-migration among the Rajbanshi population started. Nevertheless, the information obtained out of interviews put forward an idea that this out-migration started from 1965 onwards and was in its peak since the 1990's. What led to this situation needs to be analyzed in terms of both levels of development of the district as well as the condition of the community.

Koch Bihar district comprised of a large percentage of scheduled caste population, which was about 50.17 percent of its total population in 2011 and ranked first when compared with all other districts of West Bengal. The concentration of scheduled caste population increased between 1971(47.03 percent) and 1991(51.76 percent). It slightly diminished between 1991 and 2001(50.17 percent) and remained constant in 2011. The Rajbanshi community comprised about 75 percent, 78 percent and 77 percent of the total scheduled caste population of the district in 2011, 2001 and 1991 respectively. The population density of Koch Bihar district increased between 1961(301 persons per square kilometer) and 2011(832 persons per square kilometer).

\footnotetext{
${ }^{1}$ The Rajbanshi community imagine 'Kamtapur' as their homeland.

${ }^{2}$ Purposeful random sampling is one of the purposeful sampling strategies. Under this type of sampling first a population based on research, interest is identified and then the cases are selected randomly without any prior knowledge of the outcomes. The credibility of outcomes increases under this kind of purposive sampling (Palinkas et al. 2013).

${ }^{3}$ It emerged of as finding a single winner in an election and is known as Borda count. This is done by ranking of candidates by the voters in which they order their preferences. This method was formulated by Jean-Charles de Borda. Later Dasgupta and Weale (1992) used Borda rule for measuring the quality of life. Noorbaksh (1998) used Borda rule for measuring human development.
}

DOI: 10.9790/0837-2205090108 www.iosrjournals.org $3 \mid$ Page


However, it was lower than that of the State during the same period. In 2011, the district was categorized with low Population density.

The district's sex ratio between 1961(889 females per thousand males) and 2001(949 females per thousand males) was higher than the State average but it became slightly lesser in 2011(942 females per thousand males) compared to the State average (949 females per thousand males). Nevertheless, Koch Bihar had a favourable sex ratio since 1961 onwards. During 2011, the district was under moderate category when compared to all other districts of West Bengal. In addition, the Rajbanshi population also had a favourable sex ratio over the years (943 females per thousand males in 2011). This tendency in Koch Bihar district over the years might be due to male selective and family migration ${ }^{4}$. This may be possibly the case among the Rajbanshis also.

This particular district is low urbanized. During 2011, it was having only 10 percent urban population and ranked eighteen when compared with all other districts of West Bengal. Only three percent of the Rajbanshi population in the district was urbanized. Although Koch Bihar had a moderate literacy rate of 75 percent in 2011 with a narrowing male-female gap but in terms of level of education, about 28 percent were in below primary level, 29 percent in primary and 22 percent in high school level. Only seven percent, eight percent and four percent of the total literates were having secondary, higher secondary and three-year degree level of education respectively. The literacy rate of rural scheduled caste population was 84 percent with a narrowing male-female gap. However, in terms of level of education, 29 percent was in below primary level, 31 percent in primary and 22 percent in high school level, seven percent in secondary, six percent in higher secondary and a miniscule of two percent in college education. According to the Borda Composite Index constructed for demographic attributes, Koch Bihar ranked sixteenth out of nineteen districts.

Table 1: Borda Composite Score of Demographic Indicators

\begin{tabular}{|c|c|c|c|c|c|c|}
\hline \multirow[b]{2}{*}{ District } & \multicolumn{4}{|c|}{ Rank of } & \multirow[b]{2}{*}{$\begin{array}{c}\text { Composite } \\
\text { Score }\end{array}$} & \multirow{2}{*}{$\begin{array}{c}\text { Borda } \\
\text { Rank }\end{array}$} \\
\hline & $\begin{array}{c}\text { Population } \\
\text { Density }\end{array}$ & $\begin{array}{c}\text { Level of } \\
\text { Urbanization }\end{array}$ & $\begin{array}{c}\text { Sex } \\
\text { Ratio }\end{array}$ & $\begin{array}{c}\text { Literacy } \\
\text { Rate }\end{array}$ & & \\
\hline Bankura & 18 & 19 & 6 & 15 & 58 & 18 \\
\hline Barddhaman & 7 & 4 & 13 & 9 & 33 & 6 \\
\hline Birbhum & 13 & 13 & 7 & 14 & 47 & 12 \\
\hline Dakshin Dinajpur & 14 & 11 & 9 & 13 & 47 & 13 \\
\hline Darjiling & 17 & 5 & 1 & 6 & 29 & 5 \\
\hline Purba Medinipur & 8 & 17 & 18 & 1 & 44 & 11 \\
\hline Haora & 2 & 2 & 16 & 4 & 24 & 4 \\
\hline Hugli & 4 & 6 & 3 & 5 & 18 & 1 \\
\hline Jalpaiguri & 16 & 8 & 11 & 12 & 47 & 14 \\
\hline Koch Bihar & 11 & 18 & 15 & 11 & 55 & 16 \\
\hline Kolkata & 1 & 1 & 19 & 2 & 23 & 3 \\
\hline Maldah & 9 & 12 & 14 & 18 & 53 & 15 \\
\hline Murshidabad & 5 & 10 & 4 & 16 & 35 & 7 \\
\hline Nadia & 6 & 7 & 12 & 10 & 35 & 8 \\
\hline $\begin{array}{c}\text { North Twenty Four } \\
\text { Parganas }\end{array}$ & 3 & 3 & 10 & 3 & 19 & 2 \\
\hline Puruliya & 19 & 14 & 5 & 17 & 55 & 17 \\
\hline $\begin{array}{c}\text { South Twenty Four } \\
\text { Parganas }\end{array}$ & 12 & 9 & 8 & 8 & 37 & 9 \\
\hline Uttar Dinajpur & 10 & 16 & 17 & 19 & 62 & 19 \\
\hline Paschim Medinipur & 15 & 15 & 2 & 7 & 39 & 10 \\
\hline
\end{tabular}

Data Source: Computed from the census data 2011

A look into the occupational structure of Koch Bihar reveals that about 32.34 percent and 34.74 percent of the total workers were cultivators and agricultural labourers respectively. Among the rural scheduled caste community about 33 percent and 26 percent of the total workers were cultivators and agricultural labourers. Therefore, it is well understood that more than 50 percent of the total population in both the cases were engaged in agriculture according to census 2011. However, agriculture and allied activities contributed only 37 percent of the NDDP at constant (2004-2005) prices during 2012-13. The highest and the lowest contributor were tertiary sector (54 percent) and secondary sector (nine percent) respectively. Compared to the other districts of West

\footnotetext{
${ }^{4}$ Report on comparative backwardness of North Bengal region, 2002 
Out-Migration in Search of Livelihood: A study of the Rajbanshi Migrants from Koch Bihar, West ..

Bengal, Koch Bihar comprised of only about 2.24 percent of the Net State Domestic Product at constant (20042005) prices and ranked fifteenth. In terms of contribution to the Net State Domestic Product at constant (20042005) prices during 2012-13, Koch Bihar is one of the lowest contributor. Koch Bihar district's contribution towards different sectors of Net State Domestic Product at constant (2004-2005) prices during 2012-13 shows that it was a moderate contributor (4.65 percent and ranked eleventh) in case of agriculture and allied sectors and lowest contributor in case of both industries (1.19 percent and ranked seventeenth) and service sector (1.78 percent and ranked seventeenth). Although the per capita income of Koch Bihar was raised from Rs. 18,356 to Rs. 23,891 between 2004-05 and 2012-13 but then it ranked 13th when compared with all other districts of West Bengal. Koch Bihar ranked sixteenth out of nineteen districts when compared based on the Borda Composite Index values constructed for economic attributes.

Table 2: Borda Composite Score of Economic Indicators

\begin{tabular}{|c|c|c|c|c|c|c|c|}
\hline \multirow[b]{3}{*}{ District } & \multicolumn{5}{|c|}{ Rank of } & \multirow[b]{3}{*}{$\begin{array}{c}\text { Composite } \\
\text { Score }\end{array}$} & \multirow[b]{3}{*}{$\begin{array}{c}\text { Borda } \\
\text { Rank }\end{array}$} \\
\hline & \multirow[b]{2}{*}{$\begin{array}{c}\text { Distributi } \\
\text { on of } \\
\text { NSDP* }\end{array}$} & \multirow[b]{2}{*}{$\begin{array}{c}\text { Per } \\
\text { Capita } \\
\text { Income } \\
*\end{array}$} & \multicolumn{3}{|c|}{ Share in } & & \\
\hline & & & $\begin{array}{c}\text { GSDP } \\
\text { of } \\
\text { Agricultural } \\
\text { and Allied } \\
\text { Sector } \\
\end{array}$ & $\begin{array}{c}\text { GSDP of } \\
\text { Industries }\end{array}$ & $\begin{array}{c}\text { NSDP of } \\
\text { Tertiary } \\
\text { Sector }\end{array}$ & & \\
\hline Bankura & 13 & 10 & 12 & 13 & 13 & 61 & 12 \\
\hline Barddhaman & 2 & 4 & 5 & 1 & 3 & 15 & 2 \\
\hline Birbhum & 14 & 16 & 13 & 15 & 15 & 73 & 15 \\
\hline $\begin{array}{l}\text { Dakshin } \\
\text { Dinajpur }\end{array}$ & 19 & 18 & 16 & 19 & 19 & 91 & 19 \\
\hline Darjiling & 17 & 2 & 17 & 16 & 12 & 64 & 14 \\
\hline $\begin{array}{c}\text { Purba } \\
\text { Medinipur }\end{array}$ & 5 & 3 & 6 & 3 & 5 & 22 & 3 \\
\hline Haora & 7 & 5 & 18 & 4 & 6 & 40 & 7 \\
\hline Hugli & 6 & 7 & 8 & 6 & 7 & 34 & 6 \\
\hline Jalpaiguri & 11 & 9 & 10 & 11 & 11 & 52 & 11 \\
\hline Koch Bihar & 15 & 13 & 11 & 17 & 17 & 73 & 16 \\
\hline Kolkata & 3 & 1 & 19 & 8 & 2 & 33 & 5 \\
\hline Maldah & 12 & 14 & 9 & 12 & 14 & 61 & 13 \\
\hline Murshidabad & 8 & 15 & 1 & 7 & 9 & 40 & 8 \\
\hline Nadia & 10 & 11 & 3 & 10 & 10 & 44 & 9 \\
\hline $\begin{array}{l}\text { North Twenty } \\
\text { Four Parganas }\end{array}$ & 1 & 6 & 2 & 2 & 1 & 12 & 1 \\
\hline Puruliya & 16 & 17 & 15 & 14 & 16 & 78 & 17 \\
\hline $\begin{array}{l}\text { South Twenty } \\
\text { Four Parganas }\end{array}$ & 4 & 8 & 4 & 5 & 4 & 25 & 4 \\
\hline Uttar Dinajpur & 18 & 19 & 14 & 18 & 18 & 87 & 18 \\
\hline $\begin{array}{l}\text { Paschim } \\
\text { Medinipur }\end{array}$ & 9 & 12 & 7 & 9 & 8 & 45 & 10 \\
\hline
\end{tabular}

Data Source: Computed from the State Domestic Product and District Domestic Product of West Bengal 2013-14

*All at constant 2004-05prices for the year 2012-13

According to the socio-economic caste census 2011, out of the total rural household of Koch Bihar, only 4.26 percent of household had salaried job. In about 83.80 percent of the rural households, the highest earning member earned less than Rs. 5,000 per month. The income of the highest earning member was between Rs. 5,000 to Rs. 10,000 per month in about 11.88 percent of the rural households and 4.32 percent of the rural households earned more than Rs. 10,000 per month. The Borda Composite Index constructed for rural employment and income shows that Koch Bihar ranked fourteenth out of eighteen districts. Among the rural scheduled caste households of Koch Bihar about 82 percent are deprived households. Only four percent of the rural scheduled caste households were engaged in salaried job. The highest earning member of about 87 percent of the rural scheduled caste households earned less than Rs. 5,000 per month. 
Out-Migration in Search of Livelihood: A study of the Rajbanshi Migrants from Koch Bihar, West ..

Table 3: Borda Composite Score of Employment and Income of Rural Households

\begin{tabular}{|c|c|c|c|c|c|}
\hline \multirow[b]{2}{*}{ District } & \multicolumn{3}{|c|}{ Rank of } & \multirow[b]{2}{*}{$\begin{array}{c}\text { Composite } \\
\text { Score }\end{array}$} & \multirow[b]{2}{*}{$\begin{array}{c}\text { Borda } \\
\text { Rank }\end{array}$} \\
\hline & $\begin{array}{l}\text { Engaged in } \\
\text { Salaried Job }\end{array}$ & $\begin{array}{c}\text { Income } \\
\text { Between Rs. } \\
\text { 5000-10000 }\end{array}$ & $\begin{array}{c}\text { Income Above } \\
\text { Rs. } 10000\end{array}$ & & \\
\hline Bankura & 6 & 15 & 6 & 27 & 9 \\
\hline Barddhaman & 5 & 11 & 2 & 18 & 4 \\
\hline Birbhum & 13 & 16 & 13 & 42 & 16 \\
\hline Dakshin Dinajpur & 16 & 17 & 18 & 51 & 18 \\
\hline Darjiling & 1 & 4 & 1 & 6 & 1 \\
\hline Purba Medinipur & 9 & 8 & 7 & 24 & 6 \\
\hline Haora & 2 & 1 & 4 & 7 & 2 \\
\hline Hugli & 4 & 2 & 3 & 9 & 3 \\
\hline Jalpaiguri & 3 & 12 & 9 & 24 & 7 \\
\hline Koch Bihar & 18 & 6 & 14 & 38 & 14 \\
\hline Maldah & 14 & 13 & 16 & 43 & 17 \\
\hline Murshidabad & 17 & 9 & 15 & 41 & 15 \\
\hline Nadia & 12 & 3 & 5 & 20 & 5 \\
\hline $\begin{array}{l}\text { North Twenty } \\
\text { Four Parganas }\end{array}$ & 10 & 10 & 10 & 30 & 10 \\
\hline Puruliya & 8 & 18 & 8 & 34 & 11 \\
\hline $\begin{array}{l}\text { South Twenty } \\
\text { Four Parganas }\end{array}$ & 7 & 7 & 12 & 26 & 8 \\
\hline Uttar Dinajpur & 15 & 5 & 17 & 37 & 13 \\
\hline $\begin{array}{l}\text { Paschim } \\
\text { Medinipur }\end{array}$ & 11 & 14 & 11 & 36 & 12 \\
\hline
\end{tabular}

Data Source: Computed from Socio Economic Caste Census 2011.

Analyzing the village level data for the different districts in 2011 provides us a clear idea about the condition of villages in Koch Bihar in terms of availability of different amenities compared to other districts of West Bengal. In Koch Bihar 90 percent of villages had educational facilities (ranked twelfth), 52 percent of villages had medical facilities (ranked thirteenth), 99 percent of villages had drinking water facilities (ranked ninth), 24 percent of villages had post office (ranked ninth), 89 percent of villages had telephone connections (ranked sixteenth), 32 percent of villages had transport and communication facilities (ranked twelfth), eight percent of villages had banking facilities (ranked tenth), nine percent of villages had agricultural and credit societies (ranked ninth), 49 percent of villages were approached by pucca roads (ranked sixth) and all the villages were electrified ${ }^{5}$. According to the Borda Composite Index constructed for percentage of villages having different amenities, Koch Bihar ranked eleventh out of eighteen districts excluding Kolkata.

Table 4: Borda Composite Score for Percentage of Villages Having Different Amenities

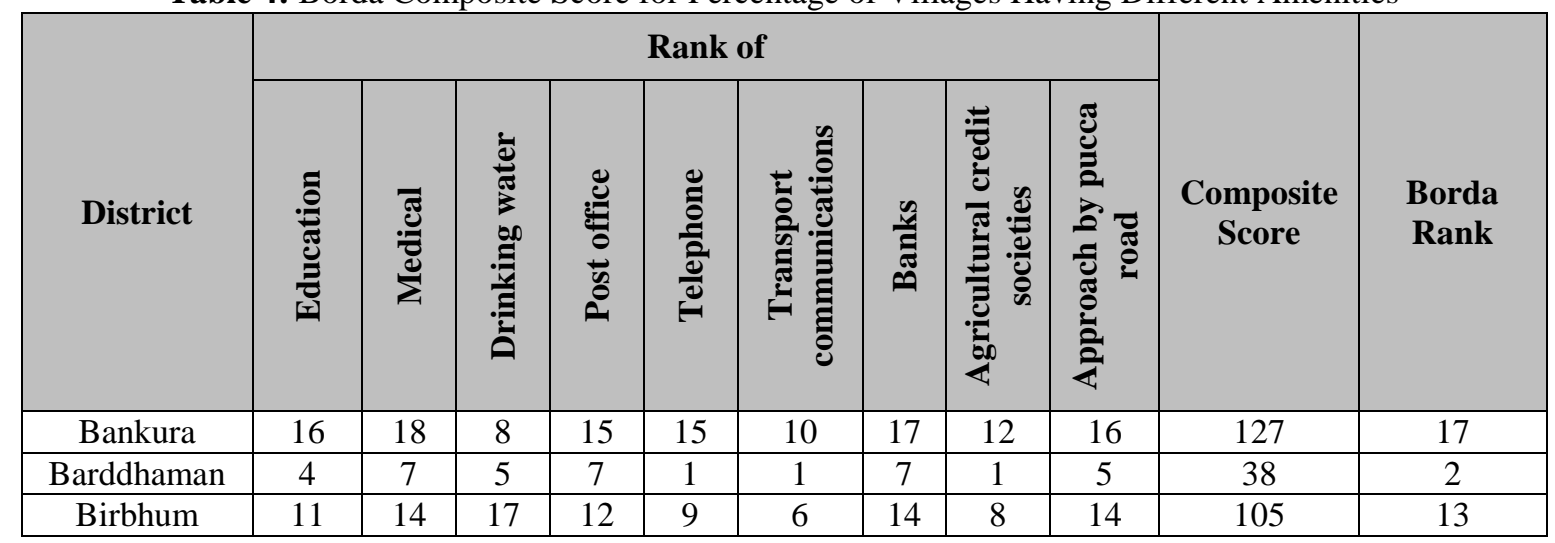

Table continued

${ }^{5}$ This is similar in other districts also. 


\begin{tabular}{|c|c|c|c|c|c|c|c|c|c|c|c|}
\hline \multirow[b]{2}{*}{ District } & \multicolumn{9}{|c|}{ Rank of } & \multirow[b]{2}{*}{$\begin{array}{c}\text { Composite } \\
\text { Score }\end{array}$} & \multirow[b]{2}{*}{$\begin{array}{l}\text { Borda } \\
\text { Rank }\end{array}$} \\
\hline & 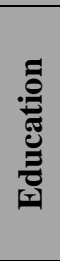 & 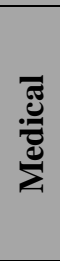 & 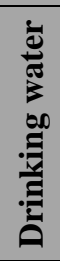 & 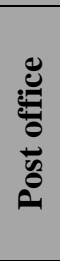 & $\frac{\stackrel{0}{\frac{\pi}{2}}}{\frac{0}{0}}$ & 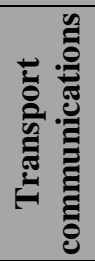 & $\frac{n}{\Xi}$ & 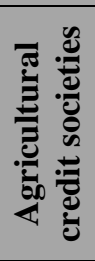 & 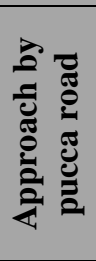 & & \\
\hline $\begin{array}{l}\text { Dakshin } \\
\text { Dinajpur }\end{array}$ & 17 & 16 & 6 & 17 & 11 & 14 & 16 & 14 & 8 & 119 & 14 \\
\hline Darjiling & 14 & 11 & 10 & 3 & 13 & 16 & 9 & 13 & 1 & 90 & 9 \\
\hline $\begin{array}{c}\text { Purba } \\
\text { Medinipur }\end{array}$ & 13 & 5 & 16 & 11 & 5 & 13 & 11 & 2 & 17 & 93 & 10 \\
\hline Haora & 1 & 1 & 18 & 8 & 6 & 4 & 5 & 5 & 7 & 55 & 6 \\
\hline Hugli & 8 & 8 & 3 & 10 & 2 & 5 & 3 & 3 & 10 & 52 & 4 \\
\hline Koch Bihar & 12 & 13 & 9 & 9 & 16 & 12 & 10 & 9 & 6 & 96 & 11 \\
\hline Maldah & 15 & 12 & 13 & 14 & 12 & 17 & 12 & 15 & 13 & 123 & 15 \\
\hline Murshidabad & 7 & 6 & 7 & 5 & 8 & 8 & 6 & 7 & 11 & 65 & 7 \\
\hline Nadia & 6 & 9 & 4 & 4 & 3 & 3 & 1 & 4 & 2 & 36 & 1 \\
\hline $\begin{array}{c}\text { North } \\
\text { Twenty Four } \\
\text { Parganas }\end{array}$ & 3 & 2 & 2 & 6 & 7 & 7 & 2 & 6 & 3 & 38 & 3 \\
\hline Puruliya & 9 & 15 & 12 & 13 & 18 & 11 & 15 & 17 & 15 & 125 & 16 \\
\hline $\begin{array}{c}\text { South } \\
\text { Twenty Four } \\
\text { Parganas }\end{array}$ & 5 & 4 & 15 & 2 & 10 & 9 & 8 & 16 & 12 & 81 & 8 \\
\hline $\begin{array}{c}\text { Uttar } \\
\text { Dinajpur }\end{array}$ & 10 & 10 & 1 & 16 & 4 & 15 & 13 & 18 & 9 & 96 & 12 \\
\hline $\begin{array}{c}\text { Paschim } \\
\text { Medinipur }\end{array}$ & 18 & 17 & 11 & 18 & 17 & 18 & 18 & 11 & 18 & 146 & 18 \\
\hline
\end{tabular}

\section{CONCLUSION}

Out of this analysis, it is evident that Koch Bihar has recorded low level of development based on Borda Composite Values of demographic, economic and employment as well as income indicators. It was having moderate level of development only in terms of percentage of villages having different amenities. In addition, from the rural scheduled caste data of Koch Bihar it can be deducted that a large section of Rajbanshi community in the district were under deprivation. This shows that the people belonging to the Rajbanshi community in Koch Bihar were compelled to migrate to ther destination due to low level of development in the district. It is quite possible that deprived sections of other communities are also migrating out of Koch Bihar. However, dearth of community level data restricts a researcher from analyzing it.

\section{REFERENCES}

[1]. Jan Bremen, Taming the coolie beast: Plantation society and the colonial order in South East Asia (Oxford University Press, New Delhi, 1989).

[2]. T. Stavros Constantinou and D. Nicholas Dimantides, Modeling international migration: determinants of emigration from Greece to the United States, 1820-1980, Annals of the Association of American Geographers, Vol. 75, 1985, 352-369.

[3]. Partha Dasgupta and Martin Weale, On measuring the quality of life, World Development, Vol. 20, 1992, $119-131$.

[4]. Vinay Gidwani, and K. Sivaramakrishnan, Circular migration and the spaces of cultural assertion, Annals of the Association of American Geographers, Vol. 93, 2003, 186-213.

[5]. John Harris and Michael Todaro, Migration,unemployment and development: a two-sector analysis, American Economic Review, Vol. 60, 1970, 126-142.

[6]. Gillian Hart, Interlocking transactions: obstacles, precursors or instruments of agrarian capitalism, Journal of Development Economics, Vol. 23, 1986, 177-203.

[7]. Karl Kautsky, The Agrarian Question, 2 vols. (translated by Pete Burgess) (Zwan Publications, London, 1988). 
[8]. C. Omar Kebbeh, The Gambia: migration in Africa's "Smiling Coast", The Online Journal of the Migration Policy Institute, 2013. Retrived 10th January, 2017 from http://ssrn.com/abstract=2429807

[9]. Brad Kress, Burkina Faso: testing the tradition of circular migration, The Online Journal of the Migration Policy Institute, 2006. Retrived 10th January, 2017 from www.migrationpolicy.org/article/burkina-fasotesting-tradition-circular-migration

[10]. Victoria A. Lawson and Lawrence A. Brown, Structural tension, migration and development: a case study of Venejuela, Professional Geographer, Vol. 39, 1987, 179-188.

[11]. W. Arthur Lewis, Economic development with unlimited supplies of labour, The Manchester School, Vol. 22, 1954, 139-191.

[12]. Emma Lundholm, Jorgen Garvill, Gunnar Malmberg and Kerstin Westin, Forced or free movers? The motives, voluntariness and selectivity of international migration in the Nordic countries. Population Space and Place, Vol. 10, 2004, 59-72.

[13]. Farhad Noorbakhsh, The human development index: some technical issues and alternative indices, Journal of International development, Vol. 10, 1998, 589-605.

[14]. Lawrence A. Palinkas, Sarah M. Horwitz, Carla A. Green, Jennifer P. Wisdom, Naihua Duan and Kimberly Hoagwood, Purposeful Sampling for Qualitative Data Collection and Analysis in Mixed Method Implementation Research, Administration and Policy in Mental Health and Mental Health Services Research, 2013. Retrived 10th January, 2017 from https://www.researchgate.net/publication/258315317_Purposeful_Sampling_for_Qualitative_Data_Colle ction_and_Analysis_in_Mixed_Method_Implementation_Research?enrichId=rgreq-c9b77762-dd0d4290-94814193cfc6134d\&enrichSource=Y292ZXJQYWd1OzI1ODMxNTMxNztBUzoxMzA1MDE2NzExMzMxO DRAMTQwODEyNTQzMTQ3MQpercent3Dpercent3D\&el=1_x_3

[15]. Genevieve Parente, Nikolay Shiklomanov and Dmitry Streletskiy, Living in the new north: migration to and from Russian Arctic cities. Focus on Geography, Vol. 55, 2012, 77-89.

[16]. R. Pincus Jonathan, Class power and agrarian change land and labour in rural West Java (United Kingdom, Palgrave Macmillan UK, 1996).

[17]. G. Ranis, and J. C. Fei, A theory of economic development, American Ecoomic Review, Vol. 51, 1961, 533-558.

[18]. E. G. Ravenstine, The laws of migration, Journal of Statistical society of London, Vol. 48, 1885, 167235.

[19]. Report on comparative backwardness of North Bengal region, 2002.

[20]. Nanda R. Shrestha, The political economy of economic underdevelopment and external migration in Nepal, Political Geography Quarterly, Vol. 4, 1985, 289-306.

[21]. Socio Economic Caste Census 2011.

[22]. Dhananjayan Sriskandarajah, The migration development nexus: Srilanka case study, International Migration,Vol. 40, 2002, 283-307.

[23]. State Domestic Product and District Domestic Product of West Bengal 2013-14.

[24]. Raul Delgado Wise, The migration and labor question today: imperialism, unequal development and forced migration. Monthly Review, Vol. 64, 2013. Retrived 10th January, 2017 from http://monthlyreview.org/2013/02/01/the-migration-and-labor-question-today-imperialism-unequaldevelopment-and-forced-migration/ 